\title{
Expression of Inoculum and Family Specific Responses in the Ponderosa Pine-Western Gall Rust Pathosystem
}

James A. Walla, North Dakota State University, Fargo 58105; Gerald A. Tuskan, Environmental Sciences Division, Oak Ridge National Laboratory, Oak Ridge, TN 37831; John E. Lundquist, U.S. Forest Service, Rocky Mountain Forest and Range Experiment Station, Ft. Collins, CO 80523; and Chengguo Wang, South Dakota State University, Brookings 57007

\begin{abstract}
Walla, J. A., Tuskan, G. A., Lundquist, J. E., and Wang, C. 1997. Expression of inoculum and family specific responses in the ponderosa pine-western gall rust pathosystem. Plant Dis. 81:5762 .

Host-pathogen interactions in the ponderosa pine-western gall rust pathosystem were studied using seedlings from eight open-pollinated mother-tree families and Peridermium harknessii aeciospores from two geographically separate sources. Pregall symptoms occurred on seedlings by 4 days after inoculation (DAI). Gall occurrence was essentially complete by 230 DAI. Of three measured pigments, light red and dark red pigments on the needles developed most rapidly. Light red pigment on the base of the needles between 21 and 66 DAI was the pregall symptom most often (i) affected by inoculum source and host family, and (ii) correlated to gall width. Pre- and postgall symptoms varied significantly (i) between inocula, and (ii) among mother-tree families. No relationship was found between field resistance ratings of the mother trees and the expression of resistance in their progeny. The inocula varied in pathogenicity, and the seedling families varied in response to infection, as shown by differences in level of incidence and site of development of pigmentation and gall size on inoculated seedlings.
\end{abstract}

Additional keywords: disease resistance, Pinus ponderosa

Western gall rust, caused by Peridermium harknessii J.P. Moore (三Endocronartium harknessii (J.P. Moore) Y. Hiratsuka), is unusual among the pine stem rust diseases of North America because the pathogen requires no alternate host. The reduced life cycle provides the potential for rapid spread of specific pathotypes among host genotypes. Because infective aeciospores from individual galls are generally homozygous with no evident recombination $(24,31)$, the original genotype is apparently propagated from one host to another. It has been suggested that the pine-western gall rust pathosystem would be an ideal candidate for the classical and molecular study of host-pathogen interactions in forest tree populations because genotype by genotype interactions could be controlled (26). Variability in inoculation responses might be characterized while controlling variability in inoculum source and host genotype. Under such conditions, information could be generated regarding the interactions of specific $P$. harknessii and pine genotypes. With the proper hostpathogen combinations, genetic mecha-

Corresponding author: J. A. Walla

E-mail: walla@badlands.nodak.edu

Accepted for publication 25 September 1996.

Publication no. D-1996-1018-04R

(C) 1997 The American Phytopathological Society nisms of disease resistance could be identified and characterized, allowing subsequent exploitation.

Ponderosa pine (Pinus ponderosa Douglas ex Laws.) is one of the most widespread and economically important of 17 native hard pine species known to be hosts of $P$. harknessii. $P$. harknessii occurs on ponderosa pine in natural stands and plantations throughout western and northern North America (15,17,22,23,32,36). Several authors have reported variability in frequency of infections or morphology of the resulting galls among ponderosa pine seed sources and among genotypes within seed sources $(6,7,15,17,18,22)$. Resistance to western gall rust has been found to be a heritable trait in other pine host species $(4,5,8,10,28-30)$.

In addition to variability in the pine host, variation in frequency or morphology of host infections among isolates of $P$. harknessii from separate galls or from different collection sites has been reported $(9,14,30,35)$. However, such variation is not always found $(27,28)$. It is also known that isozyme profiles vary among singlegall aeciospore collections $(24,25)$. Yet the relationship between isozyme variability in the pathogen and infection frequency in the host has not been defined. P. harknessii causes a variety of symptoms on its hosts $(2,4,6,11,14,16,30,35)$. Little is known about intersymptom relationships or about the etiology of individual symptoms.
To effectively study (i) host-pathogen interactions, (ii) variation in infection frequency by pathogen isolates, or (iii) genetic variation in resistance within the host, further examination of pre- and postgall symptoms is merited. Thus, the objectives of this study were (i) to characterize the relationship between pregall symptom development and subsequent gall formation, and (ii) to determine the effects of inoculum and host family differences on pregall symptom development and subsequent gall formation in $P$. harknessii-inoculated ponderosa pine seedlings.

\section{MATERIALS AND METHODS}

Plant materials. Open-pollinated cones were collected from eight individual mother trees representing four geographic seed sources of Pinus ponderosa Douglas ex. P. Laws. var. scopulorum Engelm. One tree from each of three geographic seed sources contained in a ponderosa pine provenance study located at the University of Nebraska Horning Farm, Plattsmouth, $\left(41^{\circ} 5^{\prime} \mathrm{N}, 96^{\circ} 1^{\prime} \mathrm{W}\right)$ was selected based on previous information regarding frequency of infection of the seed sources by $P$. harknessii $(15,17,19,22)$. Mother trees that had no galls when nearby trees had many and that were in seed sources previously reported to have a low frequency of infections were selected as resistant. Mother trees that had numerous branch galls and that were in seed sources previously reported to have a high frequency of infections were selected as susceptible. The selected sources were H721 (geographic origin $\left.42^{\circ} 50^{\prime} \mathrm{N}, 100^{\circ} 35^{\prime} \mathrm{W}\right), \mathrm{H} 849\left(43^{\circ} 0^{\prime} \mathrm{N}\right.$, $\left.105^{\circ} 0^{\prime} \mathrm{W}\right)$, and $\mathrm{H} 827\left(45^{\circ} 45^{\prime} \mathrm{N}, 104^{\circ} 30^{\prime} \mathrm{W}\right)$. H827 was characterized as resistant, and H849 and H721 were characterized as susceptible. Using the same criteria, two additional resistant (DR-1 and DR-5) and three additional susceptible (DS-5, DS-6, and DS-8) mother trees were chosen from trees located in the Denbigh Experimental Forest in north central North Dakota $\left(48^{\circ} 10^{\prime} \mathrm{N}, \quad 100^{\circ} 35^{\prime} \mathrm{W}\right)$, representing a fourth seed source of unknown geographic origin(s).

Germination and growth conditions used for this study were based on our earlier studies (14). Seeds were germinated in 154 $\mathrm{cm}^{3}$ Leach tubes (Ray Leach Container Nursery, Canby, OR) containing Jiffy mix potting medium (Jiffy Products, Batavia, 
IL) in the greenhouse under $16 \mathrm{~h}$ of light. A total of 395 seedlings was evaluated.

Inoculum sources and inoculation procedures. Aeciospores were collected from two individual galls on ponderosa pine, one from the Horning Farm and the other from the North Dakota Badlands $\left(46^{\circ} 40^{\prime} \mathrm{N}, 103^{\circ} 25^{\prime} \mathrm{W}\right)$, using a vacuumpowered spore collector (24). The host at each site was ponderosa pine. Spores from each gall were desiccated under vacuum and stored at $-74^{\circ} \mathrm{C}$ until needed. Both isolates shared the same isozyme biotype, biotype A (25). The Horning isolate, from the ponderosa pine provenance planting, was from a population that resulted from serial propagation of a single pathogen genotype (34). The Badlands isolate was from a natural ponderosa pine forest where multiple pathogen isozyme biotypes exist,

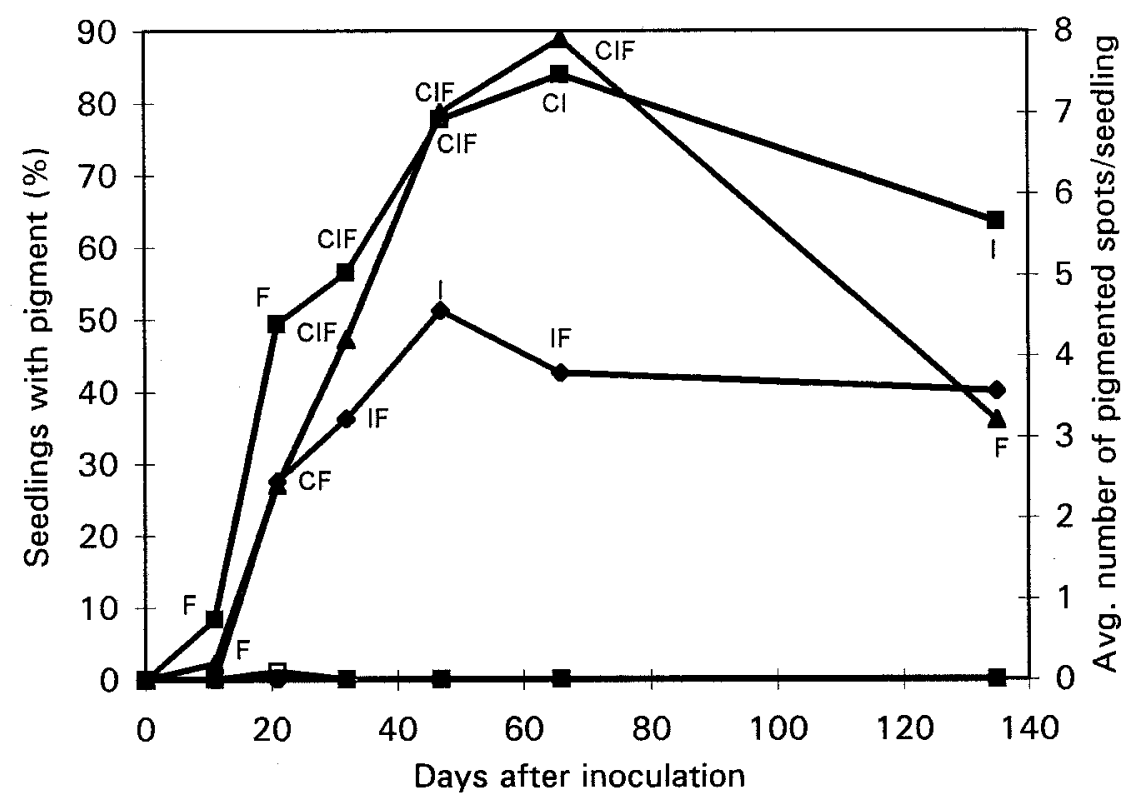

Fig. 1. Incidence of light red pigment on ponderosa pine seedlings inoculated with spores of Peridermium harknessii. Percentage of seedlings with pigment $(\bullet)$ on needles, $(\boldsymbol{\square})$ on the needle base, or $(\bullet)$ on the epicotyl; or average number of pigmented spots per seedling $(\boldsymbol{\Delta})$ at the needle base or $(\square)$ on the epicotyl. C $=$ Spearman's correlation at $\alpha<0.05$ with gall measurements at 230 days after inoculation; $\mid=$ inoculum effects at $\alpha<0.05 ; \mathrm{F}=$ family effects at $\alpha<0.05$.

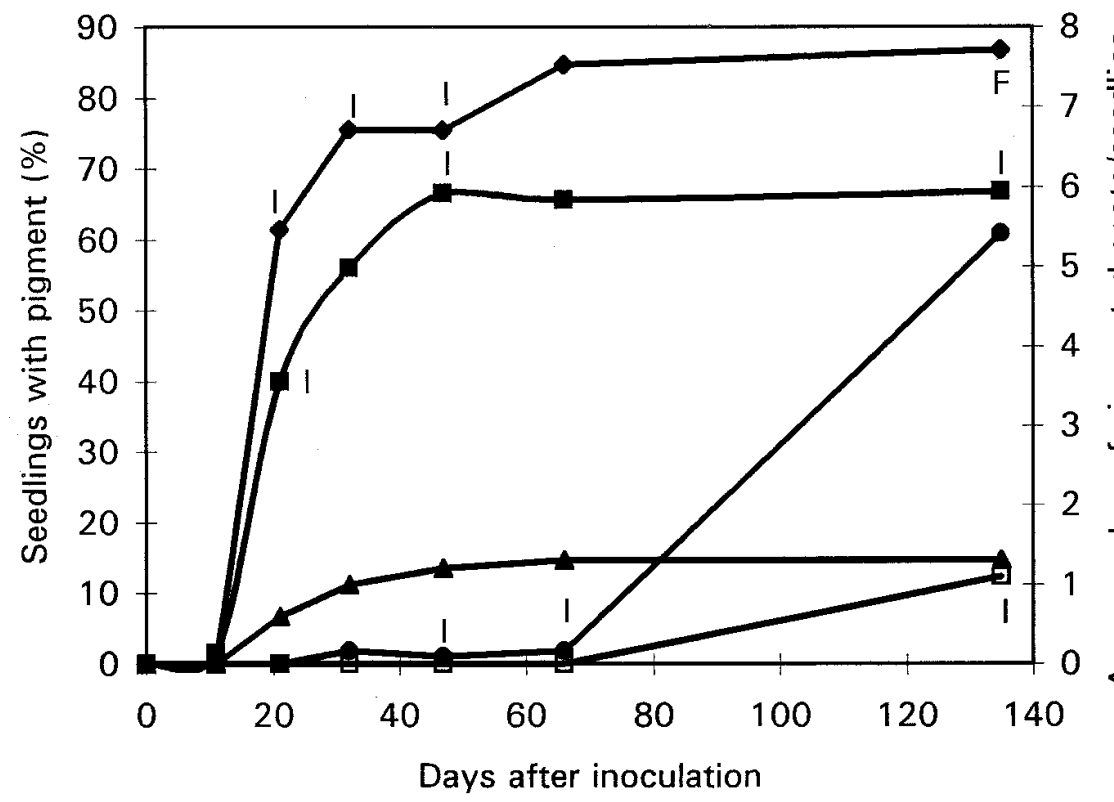

Fig. 2. Incidence of dark red pigment on ponderosa pine seedlings inoculated with spores of Peridermium harknessii. Percentage of seedlings with pigment $(\bullet)$ on needles, ( $\square)$ on the needle base, or $(\bullet)$ on the epicotyl; or average number of pigmented spots per seedling $(\boldsymbol{\Lambda})$ at the needle base or $(\square)$ on the epicotyl. $C=$ Spearman's correlation at $\alpha<0.05$ with gall measurements at 230 days after inoculation; $\mid=$ inoculum effects at $\alpha<0.05 ; \mathrm{F}=$ family effects at $\alpha<0.05$. similar to the pathogen population in the Denbigh Experimental Forest (25).

Prior to inoculation, individually labeled seedlings from each family were randomly assigned to one of two inoculum sources (blocks). The numbers of seedlings per family for the Horning and Badlands inocula, respectively, were: family H721, 37 and 37; family H827, 30 and 31; family H849, 23 and 22; family DS-5, 36 and 36; family DS-6, 20 and 14; family DS-8, 36 and 36; family DR-1, 18 and 0; family DR5,19 and 0 . Within blocks, tubes containing seedlings were placed in randomly assigned positions within 98-position tube racks. Groups of 10-day-old seedlings were inoculated by applying a compressed air stream containing $20 \mathrm{mg}$ of aeciospores suspended in $0.75 \mathrm{ml}$ of a volatile oil (Soltrol 170, Phillips Petroleum Co., Bager, TX), once each from opposite sides of each tube rack. The oil was allowed to evaporate (approximately $10 \mathrm{~min}$ ), distilled water was misted onto the seedlings to near drip point, and an empty tube rack lined with moistened paper towels was placed above the inoculated seedlings to enclose them and enhance humidity levels. An opaque, heavy-duty plastic bag was placed around the racks and the bag was sealed. Seedlings were kept in this high-humidity environment for $24 \mathrm{~h}$ at $18^{\circ} \mathrm{C}$. The bags and the upper rack were then removed to allow the seedlings to slowly dry in the dark at $18^{\circ} \mathrm{C}$ for an additional $24 \mathrm{~h}$ before being moved into the greenhouse. Spore germination was tested by placing an open petri plate containing Allen's medium (1) next to the seedling racks during inoculation. Germination rates after a $24-\mathrm{h}$ incubation period averaged $72 \%$. In the greenhouse, seedlings were maintained at an average of $24^{\circ} \mathrm{C}$ and $16-\mathrm{h}$ day length, and were watered twice weekly, with fertilizer (21-7-7 N-P-K) dissolved in the water once weekly.

Measurements and statistical analyses. Seedling size (epicotyl length) was recorded, and the seedlings were observed for western gall rust symptoms immediately before inoculation. Seedling characteristics were similar within and between blocks before inoculation. When the seedlings were 10 days old, the hypocotyl, epicotyl, cotyledonary needles, and primary needles were present. Most of the primary needles were in a plumule above the cotyledons, and the epicotyl was elongating. Secondary needles were not present. The average length of the epicotyl on these seedlings was $2.9 \mathrm{~mm}$ (range across families was 2.6 to $3.2 \mathrm{~mm}$ ). The number of primary needles appeared similar among seedlings. There were differences in the length of the primary needles associated with slight differences in the stage of development of the seedlings, as reflected in differences in epicotyl lengths.

Symptoms of western gall rust on ponderosa pine seedlings were identified in 
our earlier studies $(14,33)$. Pregall symptoms (symptoms that normally developed prior to development of galls) were assessed at 4, 7, 11, 14, 18, 21, 25, 32, 39, 47,66 , and 135 days after inoculation (DAI). These measurements included the color, incidence, number, and position of pigmented areas within the crown of each seedling. Pigment incidence was expressed as a percentage of the total seedlings per family. Recorded pigment positions included the needle, the abaxial surface of the needle base, and the epicotyl. Additional pregall symptoms included split, swollen, or stunted epicotyls, needle and seedling death, and adventitious shoot development. At 230 DAI, measurements of epicotyl length, hypocotyl diameter, presence of swellings, galls, splits, and resin on the epicotyl, and gall width and length were recorded. A swelling of the epicotyl was defined as a definite increase in width of a portion of the epicotyl in which a margin between the swollen and nonswollen epicotyl was not apparent. A gall was defined the same as a swelling, but with at least one definite margin. Gall width was recorded as an increase in size over that of the hypocotyl. The widest and longest parts of galls were measured. Hypocotyl diameter was measured just below the cotyledons. If a gall extended onto that area, the diameter was measured below the gall. At 466, 674, and 1,077 DAI, the presence of galls was recorded and compared to 230-DAI measurements.

Family and inoculum effects were tested using an $8 \times 2$ factorial experiment in a completely random design based on the following model: $Y_{i j k}=\mu_{i j k}+F_{i}+I_{j}+F I_{i j}+$ $\varepsilon_{k(i j)}$ where $Y_{i j k}=$ individual measurement of the $k$ th seedling in the $i$ th family with the $j$ th inoculum; $\mu_{i j k}=$ the overall mean effect for all $i j k$ 's; $F_{i}=$ the family effect, $i$ $=1,2 \ldots f=8 ; I_{j}=$ the inoculum effect, $j=$ $1,2 \ldots w=2$; and $\varepsilon_{k(i j)}=$ the error effect, $k$ $=1,2 \ldots s \geq 20$ for all $i j$ 's. When significant family differences were indicated, a Waller-Duncan $k$-ratio $t$ test was used to separate mean differences. Single-degreeof-freedom contrasts were used to test for differences between susceptible and resistant mother-tree families. Frequency data were transformed using an arcsine transformation and analyzed on a cell-mean basis. Data within the text have been transformed back into the original units. Spearman's rank correlation coefficients were calculated among all pregall symptom measurements and subsequent gall measurements on a family mean basis. All statistical tests were performed at $\alpha \leq 0.05$ and were generated using SAS Version $6.03(20)$.

\section{RESULTS}

Symptom development. The first disease symptoms were pigmented areas of different shapes and sizes on needles and needle bases. Three pigment colors (light red, dark red, and yellow) were seen. Light red pigment occurred as spots with diffuse margins on needles and needle bases. When on needle bases, these spots were centered on the middle of the abaxial surface of the needle base and occurred over part or all of the needle base. When on needles, these spots varied widely in size, shape, and location. Dark red pigment occurred as spots and streaks with welldefined margins on needles, needle bases, and epicotyls. Dark red pigment on needles often occurred initially as circular spots less than $0.5 \mathrm{~mm}$ diameter. In many cases, a narrow streak of dark red pigment subsequently extended from the spot toward the needle base. These streaks ranged in length from less than $1 \mathrm{~mm}$ to more than $10 \mathrm{~mm}$ and were less than $1 \mathrm{~mm}$ wide. Dark red pigmentation on the needle base and epicotyl most often occurred as short streaks, usually about $1 \mathrm{~mm}$ wide and less than 5 $\mathrm{mm}$ long. Yellow pigment occurred as spots with either well-defined or diffuse margins, primarily on needles. Yellow spots with well-defined margins appeared very similar to, but were much less common than, dark red spots on needles. Yellow spots with diffuse margins often developed around or adjacent to dark red spots on needles and varied widely in size and shape.

Light red pigment was first observed at the base of needles at 4 DAI. Dark red pigment and yellow pigment developed on needles by 11 DAI. Percentage of seedlings with light red or dark red pigments on the needles and needle bases, and the number of needle bases per seedling with light red pigment, increased until about 66 DAI (Figs. 1 and 2). The incidence of light red pigment on the epicotyl remained relatively low throughout the study. Dark red pigment was detected on seedling epicotyls by $25 \mathrm{DAI}$, but the number of seedlings with this trait remained low until after 66 DAI. Dark red pigment on the epicotyl increased, while the occurrence of light red pigment at the needle base decreased (disappeared) after 66 DAI. Nearly all seedlings with dark red pigment on the epicotyl previously had dark red pigment at the needle base. Likewise, all seedlings with dark red pigment at the needle base previously had dark red pigment on the needles. Dark red pigment often developed sequentially, initially developing on the needle, extending to the needle base and then to the epicotyl. However, the dark red pigment occasionally developed solely on the epicotyl, and dark red pigment did not always continue development; i.e., sometimes pigment on the needle or needle base did not extend to other tissues. After galls or swellings developed, dark red pigment sometimes extended from the epicotyl to the needle base and occasionally to the primary needle. The percentage of seedlings with yellow pigment increased to a maximum of $77 \%$ at 135 DAI (data not shown). This response, however, was not related to inoculum, host family, or subsequent gall formation and was thus deleted from further analyses.

At 135 DAI, the occurrence of dark red pigment on most tissues had been maintained at or increased to its maximum incidence, light red pigment at the needle base had decreased, abnormal splits in the epicotyl had developed on some seedlings, swelling on the epicotyl had developed on many seedlings, and galls were apparent on a few seedlings. The splits were longitudinal along the epicotyl, less than $10 \mathrm{~mm}$ long and $5 \mathrm{~mm}$ wide, and appeared similar to those reported by others $(2,16,30)$. Pregall symptoms of western gall rust were not seen on the hypocotyl or cotyledons.

The presence of galls at 230 DAI gave a close estimate of the seedlings in which infections had resulted in galls that could continue development through sporulation. Only six seedlings developed additional galls between 230 DAI and 1,077 DAI, so symptoms at 230 DAI were used to assess infection level. All galls initially developed on the epicotyl; some galls elongated down into the hypocotyl and up to the terminal bud of the seedling. At 230 DAI, stem galls were present on $81 \%$ ( 315 out of 389 remaining live seedlings) of the seedlings. Ninety-three percent of the seedlings that developed dark red pigment on the epicotyl developed galls; such seedlings comprised $65 \%$ (205 seedlings) of those with galls. Likewise, $83 \%$ of the seedlings with dark red pigment at the needle base, but not on

Table 1. Analysis of variance results for ponderosa pine seedlings 230 days after inoculation with Peridermium harknessii based on eight open-pollinated ponderosa pine families and two geographically distinct inocula of $P$. harknessii

\begin{tabular}{|c|c|c|c|c|c|c|c|}
\hline $\begin{array}{l}\text { Source of } \\
\text { variation }\end{array}$ & $\begin{array}{c}\text { Frequency of } \\
\text { gall formation }\end{array}$ & $\begin{array}{c}\text { Frequency of } \\
\text { resin formation }\end{array}$ & Gall width & Gall length & Gall volume & Epicotyl length & $\begin{array}{c}\text { Hypocotyl } \\
\text { diameter }\end{array}$ \\
\hline Family (F) & $\mathrm{NS}^{\mathrm{y}}$ & NS & $* *$ & $* *$ & ** & ** & $* *$ \\
\hline Inoculum (I) & NS & NS & $* *$ & $* *$ & $*$ & NS & $* *$ \\
\hline$F^{*} \mathrm{I}$ & $\ldots^{\mathrm{z}}$ & $\ldots$ & $* *$ & NS & NS & NS & NS \\
\hline
\end{tabular}

y ** indicates a significant $F$ value at $P \leq 0.01$, * indicates a significant $F$ value at $P \leq 0.05$, and NS indicates a nonsignificant $F$ value at $P>0.05$.

${ }^{\mathrm{z}}$ Frequency data were analyzed on a plot-mean basis, and therefore a test for the family by inoculum interaction did not exist. 
the epicotyl, developed galls; such seedlings comprised $21 \%$ (66 seedlings) of those with galls. Fifty percent of the seedlings with dark red pigment on needles, but not at the needle base or on the epicotyl, developed galls; such seedlings comprised $10 \%$ (32 seedlings) of those with galls. Thus, $96 \%$ of the seedlings with galls had previously developed dark red pigment on some tissue. The remaining $4 \%$ of the seedlings with galls had either light red pigment or no symptoms. Occurrence of dark red pigment closer to the epicotyl was associated with an increased likelihood that a gall would later develop. Ninety-three percent of the seedlings with abnormal splits in the epicotyl developed galls; such

Table 2. Differences across time in ponderosa pine seedlings inoculated at age 10 days using two geographically distinct isolates of Peridermium harknessii

\begin{tabular}{llcc}
\hline \multirow{2}{*}{ Seedling age } & Symptom & \multicolumn{2}{c}{ Inoculum $^{\mathbf{y}}$} \\
\cline { 3 - 4 } (position/pigment) & Horning & Badlands \\
\hline \multirow{3}{*}{32 DAI ${ }^{z}$} & Needle/dark red (\%) & 54 & 76 \\
& Needle base/dark red (\%) & 45 & 29 \\
& Needle base/light red (\%) & 44 & 82 \\
& Needle base/light red (no.) & 2 & 7 \\
& Needle/light red (\%) & 28 & 52 \\
47 DAI & Needle/dark red (\%) & 70 & 86 \\
& Needle base/light red (\%) & 71 & 92 \\
& Needle base/light red (no.) & 5 & 9 \\
& Needle/light red (\%) & 56 & 41 \\
& Needle/dark red (\%) & 70 & 37 \\
& Epicotyl/dark red (\%) & 0 & 3 \\
& Needle base/light red (\%) & 79 & 10 \\
& Needle base/light red (no.) & 6 & 30 \\
& Needle/light red (\%) & 49 & 7 \\
& Epicotyl/dark red (\%) & 0 & 49 \\
& Needle base/light red (\%) & 71 & 53 \\
& Needle base/dark red (\%) & 74 & 42 \\
& Epicotyl/dark red (\%) & 70 & 0.7 \\
& Epicotyl/dark red (no.) & 1.4 & 3.0 \\
& Gall width (mm) & 2.4 & 17 \\
\hline
\end{tabular}

y Analysis of variance $F$ tests indicated significant differences in inoculum sources at $P \leq 0.05$ for all the listed symptoms.

${ }^{\mathrm{z}}$ Days after inoculation.

Table 3. Family mean differences for symptom frequency per family associated with the inoculation of 10-day-old ponderosa pine seedlings using Peridermium harknessii spores

\begin{tabular}{|c|c|c|c|c|c|c|c|}
\hline \multirow[b]{2}{*}{ Family } & \multicolumn{2}{|c|}{$\begin{array}{c}\text { Light red pigment } \\
\text { on needles }(\%)\end{array}$} & \multirow{2}{*}{$\begin{array}{c}\text { Dark red } \\
\text { pigment on } \\
\text { needles (\%) } \\
135 \text { DAI }\end{array}$} & \multicolumn{4}{|c|}{ Light red pigment at the needle base (\%) } \\
\hline & 32 DAI $^{x}$ & 66 DAI & & 11 DAI & 21 DAI & 32 DAI & 47 DAI \\
\hline \multicolumn{8}{|c|}{ Susceptible } \\
\hline H721 & $65 \mathrm{a}^{\mathrm{z}}$ & $0 \mathrm{~b}$ & $90 \mathrm{a}$ & $35 \mathrm{a}$ & $92 \mathrm{a}$ & $88 \mathrm{a}$ & $92 \mathrm{a}$ \\
\hline H849 & $28 \mathrm{~b}$ & $2 \mathrm{~b}$ & $91 \mathrm{a}$ & $0 \mathrm{c}$ & $34 \mathrm{~cd}$ & 42 de & 70 a-d \\
\hline DS-6 & $18 \mathrm{~b}$ & $0 \mathrm{~b}$ & $59 \mathrm{~b}$ & $0 \mathrm{c}$ & $25 \mathrm{~d}$ & $38 \mathrm{e}$ & $59 \mathrm{~d}$ \\
\hline DS-5 & $33 \mathrm{~b}$ & $0 \mathrm{~b}$ & $91 \mathrm{a}$ & $11 \mathrm{~b}$ & $52 \mathrm{~b}$ & $60 \mathrm{bc}$ & $86 a b$ \\
\hline DS-8 & $39 \mathrm{~b}$ & $1 \mathrm{~b}$ & $96 \mathrm{a}$ & $5 \mathrm{bc}$ & $53 \mathrm{~b}$ & $66 \mathrm{~b}$ & $87 \mathrm{a}$ \\
\hline \multicolumn{8}{|c|}{ Resistant } \\
\hline H827 & $44 \mathrm{~b}$ & $2 b$ & $83 \mathrm{ab}$ & $5 \mathrm{bc}$ & $54 \mathrm{~b}$ & $59 \mathrm{~b}-\mathrm{d}$ & $84 a-c$ \\
\hline DR-1 & $32 \mathrm{~b}$ & $11 \mathrm{a}$ & $94 \mathrm{a}$ & $0 \mathrm{c}$ & $23 \mathrm{~d}$ & $37 \mathrm{e}$ & $63 \mathrm{~cd}$ \\
\hline DR-5 & $16 \mathrm{~b}$ & $0 \mathrm{~b}$ & $89 a$ & $4 \mathrm{bc}$ & $40 \mathrm{bc}$ & $42 \mathrm{c}-\mathrm{e}$ & $64 \mathrm{~b}-\mathrm{d}$ \\
\hline
\end{tabular}

${ }^{\mathrm{x}}$ Days after inoculation.

y Family classification based on phenotypic performance of the mature mother tree; single-degree-offreedom contrasts within the analyses of variance indicated no difference between open-pollinated susceptible and resistant families.

${ }^{\mathrm{z}}$ Column values followed by the same letter are not significantly different at a minimum $P \leq 0.05$ based on Waller-Duncan's $k$-ratio $t$ test. of lesions. One seedling had no observed pregall symptoms but did develop a gall.

Inoculum and host family effects. Significant inoculum and host family effects occurred more often in seedlings with light red pigment at the needle base than in those with dark red pigment (Figs. 1 and 2). Inoculum and family effects were common for light red pigment on the needles and at the needle bases between 21 and 66 DAI. Gall characteristics also differed significantly among inocula and host families (Table 1). Inoculum and family effects relative to western gall rust symptoms occurred for gall width, gall length, and gall volume at 230 DAI. A family by inoculum interaction effect was observed for gall width. Epicotyl length and hypocotyl diameter at 230 DAI differed among families. Badlands inoculum caused significantly more rapid pregall responses and larger gall dimensions than did the Horning inoculum (Tables 1 and 2). Variation was present in gall frequency among inocula and host families, but the differences were not significant (Table 1).

Family H721, a family from a susceptible mother tree, was characterized by seedlings that showed rapid, early symptom development in response to inoculation, typically developing the highest frequency of symptoms per family and the most lesions per seedling for the measured traits at each date (Tables 3 and 4). This family was also characterized by having some of the largest gall, hypocotyl, and epicotyl dimensions (Table 5). Conversely, family DS-6, a family from another susceptible mother tree, was characterized by seedlings that showed slow, late responses to inoculation and among the smallest gall widths, hypocotyl diameters, and epicotyl lengths. Of the three families from resistant mother trees, DR-1 was characterized by seedlings that had the largest gall length, and DR-1 and DR-5 were characterized by seedlings that had the largest hypocotyl diameter (Table 5). The singledegree-of-freedom contrasts between families from susceptible and resistant mother trees, for all pre- and postgall symptoms, were never significant.

Gall presence and size at 230 DAI were used for comparison with pregall symptoms. Light red pigment at the needle base was the only pregall symptom correlated to gall measurements at 230 DAI (Fig. 1). The correlation coefficient between light red pigment at the needle base and subsequent gall width at $230 \mathrm{DAI}$ was at its highest at 21 DAI $(r=0.85, P \leq 0.007)$, decreasing to $r=0.67(P \leq 0.05)$ at 47 DAI, and then increasing to $r=0.79(P \leq$ 0.02 ) at 66 DAI. Family differences, inoculum differences, and correlations to subsequent gall characteristics were not detected for light red pigment on the epicotyl. All correlations between dark red pigment on any tissue type and subsequent gall characteristics were nonsignificant 
(Fig. 2). However, dark red pigment at the needle base at 11 and 21 DAI was negatively correlated with the frequency of dead seedlings per family at 230 DAI $(r=$ $-0.73, P \leq 0.04$, and $r=-0.79, P \leq 0.02$, respectively), and dark red pigment on the needles at 66 DAI was positively correlated $(r=0.71, P \leq 0.04)$ with seedling height at 230 DAI.

\section{DISCUSSION}

Understanding the course of disease development and the relationship between early symptom expression and subsequent gall formation in the ponderosa pine-western gall rust pathosystem will aid in the characterization of genetic variation among pathogen isolates and pine host families. Ultimately, this information will contribute to more effective disease screening protocols. Results from this study indicate that disease symptomatology does vary by host family and pathogen isolate.

Relationship between early symptoms and gall formation. The strongest association between pregall symptoms and subsequent gall formation occurred with light red pigment at the needle base. The amount of light red pigment at the needle base from 21 to 66 DAI (both number of lesions per seedling and frequency per family) was associated with gall width at 230 DAI, suggesting a functional relationship between increased light red pigment and gall characteristics. Seedlings with a greater amount of light red pigment tended to develop wider galls, while seedlings with little or no light red pigment tended to develop narrower galls. Lundquist and Miller (13) reported that lesions (pigmented areas) with diffuse borders in needle axils were more common on seedlings in a family susceptible to Cronartium quercuum (Berk.) Miyabe ex Shirai f. sp. fusiforme (Hedgc. \& N. Hunt) Burdsall \& G. Snow than on seedlings in a resistant family. They demonstrated that the pathogen was present in tissues associated with those lesions. More commonly, dark red, purple, or yellow pigmentation in lesions with distinct borders has been reported as the type of pigmentation that develops when plant tissue is infected by pine stem rusts $(3,8,13)$. Such lesions have sometimes been associated with a resistance response $(8,13)$. Nevertheless, a lack of relationship between dark red pigment and gall development has been reported with $P$. harknessii infections $(1,11,30)$ and $C$. quercuum $\mathrm{f}$. sp. fusiforme infections (12).

In comparing the developmental differences between the light red pigment and dark red pigment responses across tissue types, it appears that the dark red pigment exhibits a more sequential progression (Fig. 2 versus Fig. 1). Many areas of dark red pigment developed initially on the primary needle and then expanded as a dark red streak toward the needle base. Some of the streaks continued develop- ment onto the needle base, and some of those then extended onto the epicotyl. Young galls on epicotyls were observed to be centered around some areas of dark red pigment on needle bases or epicotyls. Dark red pigment appeared to be a direct response of ponderosa pine to infection by $P$. harknessii. A "resistance mechanism" relationship between dark red pigment and gall development has been proposed for the lodgepole pine (Pinus contorta Douglas ex Loud.)-western gall rust pathosystem by Kojwang and van der Kamp (11). Alternatively, because it occurred on most needle bases of some seedlings and it appeared and disappeared over time, light red pigment at the needle base seemed to be a general physiological response, possibly one that can be induced by several stress agents, including $P$. harknessii. Our results indicated that, under otherwise unstressed conditions, the percentage of seedlings in a family with light red pigment at the needle base could be used as an early indicator of levels of infection by $P$. harknessii in the

Table 4. Family mean differences for number of symptoms per seedling associated with the inoculation of 10-day-old ponderosa pine seedlings using Peridermium harknessii spores

\begin{tabular}{lcccccc}
\hline & \multicolumn{5}{c}{ Light red pigment at needle base (average no. of spots per seedling) } \\
\cline { 2 - 6 } Family & 11 DAI & 21 DAI & 32 DAI & 47 DAI & 66 DAI & 135 DAI \\
\hline Susceptible & & & & & & \\
H721 & $35 \mathrm{a}^{\mathrm{z}}$ & $5.6 \mathrm{a}$ & $8.2 \mathrm{a}$ & $11.4 \mathrm{a}$ & $12.3 \mathrm{a}$ & $4.2 \mathrm{a}$ \\
H849 & $0 \mathrm{c}$ & $1.4 \mathrm{~b}-\mathrm{e}$ & $2.8 \mathrm{c}$ & $4.4 \mathrm{de}$ & $6.8 \mathrm{~cd}$ & $4.0 \mathrm{ab}$ \\
DS-6 & $0 \mathrm{c}$ & $0.4 \mathrm{e}$ & $1.4 \mathrm{~d}$ & $3.2 \mathrm{e}$ & $4.5 \mathrm{ef}$ & $1.8 \mathrm{~b}$ \\
DS-5 & $11 \mathrm{~b}$ & $2.3 \mathrm{~b}$ & $4.9 \mathrm{~b}$ & $7.7 \mathrm{bc}$ & $8.7 \mathrm{bc}$ & $2.8 \mathrm{ab}$ \\
DS-8 & $5 \mathrm{bc}$ & $2.2 \mathrm{bc}$ & $4.1 \mathrm{bc}$ & $8.1 \mathrm{~b}$ & $8.8 \mathrm{~b}$ & $3.5 \mathrm{ab}$ \\
Resistant & & & & & & \\
H827 & $5 \mathrm{bc}$ & $1.8 \mathrm{~b}-\mathrm{d}$ & $3.4 \mathrm{c}$ & $6.0 \mathrm{~cd}$ & $6.3 \mathrm{de}$ & $2.6 \mathrm{ab}$ \\
DR-1 & $0 \mathrm{c}$ & $0.7 \mathrm{de}$ & $0.9 \mathrm{~d}$ & $3.3 \mathrm{e}$ & $4.0 \mathrm{f}$ & $4.1 \mathrm{a}$ \\
DR-5 & $4 \mathrm{bc}$ & $1.1 \mathrm{c}-\mathrm{e}$ & $1.2 \mathrm{~d}$ & $4.6 \mathrm{de}$ & $4.1 \mathrm{f}$ & $1.8 \mathrm{~b}$ \\
\hline
\end{tabular}

${ }^{x}$ Days after inoculation.

${ }^{y}$ Family classification based on phenotypic performance of the mature mother tree; single-degree-offreedom contrasts within the analyses of variance indicated no difference between open-pollinated susceptible and resistant families.

${ }^{\mathrm{z}}$ Column values followed by the same letter are not significantly different at a minimum $P<0.05$ based on Waller-Duncan's $k$-ratio $t$ test.

Table 5. Family mean differences for gall characteristics and seedling size at 230 days after inoculation following inoculation of 10-day-old ponderosa pine seedlings using Peridermium harknessii spores

\begin{tabular}{lccccc}
\hline Family & $\begin{array}{c}\text { Gall width } \\
(\mathbf{m m})^{\mathbf{w}}\end{array}$ & $\begin{array}{c}\text { Gall length } \\
(\mathbf{m m})\end{array}$ & $\begin{array}{c}\text { Gall volume } \\
\left(\mathbf{m m}^{\mathbf{3}}\right)^{\mathbf{x}}\end{array}$ & $\begin{array}{c}\text { Hypocotyl } \\
\text { diameter }(\mathbf{m m})\end{array}$ & $\begin{array}{c}\text { Epicotyl } \\
\text { length }(\mathbf{c m})\end{array}$ \\
\hline Susceptible & & & & & \\
H721 & $2.9 \mathrm{~b}^{\mathrm{z}}$ & $17 \mathrm{bc}$ & $269 \mathrm{~b}$ & $4.3 \mathrm{a}$ & $19 \mathrm{a}$ \\
H849 & $2.8 \mathrm{bc}$ & $16 \mathrm{bc}$ & $225 \mathrm{bc}$ & $3.9 \mathrm{a}-\mathrm{c}$ & $20 \mathrm{a}$ \\
DS-6 & $1.8 \mathrm{~d}$ & $15 \mathrm{bc}$ & $133 \mathrm{c}$ & $3.6 \mathrm{~cd}$ & $15 \mathrm{c}$ \\
DS-5 & $3.8 \mathrm{a}$ & $18 \mathrm{ab}$ & $480 \mathrm{a}$ & $4.0 \mathrm{ab}$ & $20 \mathrm{a}$ \\
DS-8 & $2.1 \mathrm{~b}-\mathrm{d}$ & $14 \mathrm{c}$ & $124 \mathrm{c}$ & $3.5 \mathrm{~d}$ & $16 \mathrm{bc}$ \\
Resistant & & & & & \\
H827 & $2.5 \mathrm{~b}-\mathrm{d}$ & $13 \mathrm{c}$ & $198 \mathrm{bc}$ & $3.7 \mathrm{~b}-\mathrm{d}$ & $18 \mathrm{ab}$ \\
DR-1 & $2.3 \mathrm{~b}-\mathrm{d}$ & $21 \mathrm{a}$ & $197 \mathrm{bc}$ & $4.2 \mathrm{a}$ & $18 \mathrm{ab}$ \\
DR-5 & $2.0 \mathrm{~cd}$ & $14 \mathrm{c}$ & $198 \mathrm{bc}$ & $4.1 \mathrm{ab}$ & $19 \mathrm{a}$ \\
\hline
\end{tabular}

${ }^{\mathrm{w}}$ Gall width is reported here as the increase in size over that of the seedling hypocotyl.

${ }^{x}$ Radius used to calculate gall volume is based on gall width plus hypocotyl diameter.

${ }^{y}$ Family classification based on phenotypic performance of the mature mother tree; single-degree-offreedom contrasts within the analyses of variance indicated no difference between open-pollinated susceptible and resistant families.

${ }^{\mathrm{z}}$ Column values followed by the same letter are not significantly different at a minimum $P \leq 0.05$ based on Waller-Duncan's $k$-ratio $t$ test. 
D. Don)-western gall rust pathosystem (30). Thus, to fully characterize interaction differences in ponderosa pine, future studies should utilize multiple genetically and geographically separate, single-gall isolates of P. harknessii.

Gall dimensions were significantly affected by both inoculum and host family. Gall dimensions would likely play an important role in the epidemiology of the disease in the field. Factors such as spore production and host disruption would be directly impacted. Differences in gall shape have been used as an indication of host resistance to $C$. quercuum f. sp. fusiforme (21). Hosts with relatively short, round galls were considered to be more resistant than hosts with long, fusiform galls. However, Kuhlman and Powers (12) demonstrated that long, fusiform galls were more commonly present on infected plants in resistant families than in susceptible families. Application of such a criterion to western gall rust requires prior investigation of the genetics and epidemiological effects of gall shape.

A parent-offspring relationship across families as estimated by mother-tree ratings in the field and gall development on their progeny in the greenhouse was not detected. Both resistant and susceptible mother trees produced progeny that became heavily infected and developed galls. The apparent contradiction between field rankings and progeny performance may be due to factors such as effects of out crossing on the expression of resistance (host genetics) or to the artificial inoculation and incubation conditions (environment). Other researchers have similarly found a lack of relationship between open-pollinated progeny susceptibility to $P$. harknessii and the susceptibility of the mother tree $(11,18)$. Detection of gene-for-gene interactions was not possible in this test because there was not genetic control of the pollen parent.

In summary, of all measured pregall symptoms, light red pigment at the base of the needles between 21 and 66 DAI produced the highest correlations to presence and size of galls. The direct functional relationship between light red pigment, dark red pigment, and gall formation merits further study. Pre- and postgall symptoms varied significantly by inoculum even though both isolates shared the same isozyme biotype. Field ranking of mothertree disease resistance was not an accurate predictor of pre- and postgall symptoms on open-pollinated progeny. Nevertheless, families did vary in development of light red pigment, which was an indicator of subsequent gall formation. Family and inoculum differences in both pre- and postgall symptoms indicate there is an opportunity to select for improved $P$. harknessii resistance in ponderosa pine.

\section{ACKNOWLEDGMENTS}

Greenhouse facilities and data collection were supported by the North Dakota State Agricultural Experiment Station, Fargo, and in part by USDA grant 87-FSTY-9-0267. Data analyses and manuscript preparation were supported by the Biofuels System Division, U.S. Department of Energy, under contract DE-AC05-84OR21400 with Martin Marietta Energy Systems, Inc., Environmental Sciences Division, Oak Ridge National Laboratory.

\section{LITERATURE CITED}

1. Allen, E. A., Blenis, P. V., and Hiratsuka, Y. 1988. Axenic culture of Endocronartium harknessii. Mycologia 80:120-123.

2. Allen, E. A., Blenis, P. V., and Hiratsuka, Y. 1990. Early symptom development in lodgepole pine seedlings infected with Endocronartium harknessii. Can. J. Bot. 68:270277.

3. Allen, E. A., and Hiratsuka, Y. 1985. Artificial inoculation of young seedlings of lodgepole pine with Endocronartium harknessii. Can. J. Bot. 63:1168-1170.

4. Burnes, T. A., and Blanchette, R. A. 1991. Evaluating Scots pine for resistance to Endocronartium harknessii. For. Sci. 37:16891691.

5. Burnes, T. A., Blanchette, R. A., Wang, C.-G., and French, D. W. 1988. Screening jack pine seedlings for resistance to Endocronartium harknessii. Plant Dis. 72:614-616.

6. Hoff, R. J. 1986. Susceptibility of pine populations to western gall rust in central Idaho. U.S. Dep. Agric. For. Serv. Res. Note INT354.

7. Hoff, R. J. 1991. Resistance to western gall rust in artificially inoculated ponderosa pine. Can. J. For. Res. 21:1316-1320.

8. Kinloch, B. B., Jr., and Comstock, M. 1980. Cotyledon test for major gene resistance to white pine blister rust in sugar pine. Can. J. Bot. 58:1912-1914

9. Kojwang, H. O. 1989. Western gall rust (Endocronartium harknessii (Moore) Hirat.) on lodgepole pine (Pinus contorta Dougl.) in British Columbia - A study of variation and inheritance of resistance in a natural pathosystem. Ph.D. diss. University of British Columbia, Vancouver.

10. Kojwang, H. O. 1994. Variation and heritability of resistance of lodgepole pine to western gall rust. Eur. J. For. Pathol. 24:137-143.

11. Kojwang, H. O., and van der Kamp, B. J. 1992. Early symptoms and resistance of lodgepole pine seedlings inoculated with western gall rust. Can. J. Bot. 70:1274-1278.

12. Kuhlman, E. G., and Powers, H. R., Jr. 1988. Resistance responses in half-sib loblolly pine progenies after inoculation with Cronartium quercuum f. sp. fusiforme. Phytopathology 78:484-487.

13. Lundquist, J. E., and Miller, T. 1984. Development of stem lesions on slash pine seedlings infected by Cronartium quercuum f. sp. fusiforme. Phytopathology 74:514-518.

14. Lundquist, J. E., Tuskan, G. A., and Walla, J. A. 1991. Progress in developing early screening techniques for resistance of ponderosa pine to western gall rust. For. Can. Infor. Rep. NOR-X-317:274-280.

15. Merrill, W., Wenner, N., and Towers, B. 1986. Resistance of Pinus ponderosa to Endocronartium harknessii in Pennsylvania. Plant Dis. 70:317-320.

16. Nelson, D. L. 1970. The ecology and pathology of pine gall rust in California. Ph.D. diss. University of California, Berkeley.

17. Peterson, G. W., and Riffle, J. W. 1984. Dis- ease resistance investigations in relationship to tree improvement research in Nebraska Proc. For. Comm., Great Plains Agric Counc., Publ. 112:130-136.

18. Quick, C. R. 1966. Experimental inoculation of ponderosa pine with western gall rust. Plant Dis. Rep. 50:550-552.

19. Read, R. A. 1983. Ten-year performance of ponderosa pine provenances in the Great Plains of North America. U.S. Dep. Agric. For. Serv. Res. Pap. RM-250.

20. SAS Institute. 1988. SAS User's Guide: Statistics, Version 6.03. SAS Institute, Cary, NC.

21. Snow, G. A., Nance, W. L., and Snyder, E. B. 1982. Relative virulence of Cronartium quercuum $\mathrm{f}$. sp. fusiforme on loblolly pine from Livingston Parish. Pages 243-250 in: Resistance to Diseases and Pests in Forest Trees. H. M. Heybroek, B. R. Stephan, and K. von Weissenberg, compilers. Pudoc, Wageningen, Netherlands.

22. Thomas, C. S., Hart, J. H., and Cress, C. E. 1984. Severity of Endocronartium harknessii in two provenance stands of Pinus ponderosa in Michigan. Plant Dis. 68:681-683.

23. True, R. P. 1938. Gall development on Pinus sylvestris attacked by Woodgate Peridermium, and morphology of the parasite. Phytopathology 28:24-49.

24. Tuskan, G. A., and Walla, J. A. 1989. Isozyme characterization of Peridermium harknessii and Cronartium quercuum f. sp. banksianae with starch gel electrophoresis. Phytopathology 79:444-448.

25. Tuskan, G. A., Walla, J. A., and Lundquist, J. E. 1990. Genetic-geographic variation in Peridermium harknessii in the north-central United States. Phytopathology 80:857-861.

26. Tuskan, G. A., Walla, J. A., Lundquist, J. E., Wang, C. G., and McClean, P. 1991. The use of molecular markers in studying ponderosa pine-Peridermium harknessii interactions. For. Can. Infor. Rep. NOR-X-317:178-187.

27. van der Kamp, B. J. 1989. The relative susceptibility of Scots and lodgepole pine to western gall rust. Eur. J. For. Pathol. 19:274280.

28. van der Kamp, B. J. 1991. Major gene resistance of Scots pine to western gall rust. Can. J. For. Res. 21:375-378.

29. van der Kamp, B. J., and Tait, D. E. N. 1990 Variation in disease severity in the lodgepole pine-western gall rust pathosystem. Phytopathology 80:1269-1277.

30. Vogler, D. R. 1991. Genetic interactions in the radiata pine-western gall rust pathosystem. Ph.D. diss. University of California, Berkeley.

31. Vogler, D. R., Kinloch, B. B., Jr., Cobb, F. W., Jr., and Popenuck, T. L. 1991. Isozyme structure of Peridermium harknessii in the western United States. Can. J. Bot. 69:24342441.

32. Walla, J. A., and Stack, R. W. 1979. Western gall rust in North Dakota. Plant Dis. Rep. 63:432-433.

33. Walla, J. A., and Tuskan, G. A. 1987. Studies of western gall rust resistance in ponderosa pine. Pages 101-112 in: Proc. N. Cent. Tree Improve. Conf., 5th.

34. Walla, J. A., Tuskan, G. A., and Peterson, G. W. 1988. Enzyme analysis of Peridermium harknessii in Nebraska ponderosa pine plantings. (Abstr.) Phytopathology 78:1607.

35. Wenner, N. G., and Merrill, W. 1987. Inoculation of Scots pine to compare two inoculum sources of Endocronartium harknessii. (Abstr.) Phytopathology 77:1620.

36. Ziller, W. G. 1974. The Tree Rusts of Western Canada. Publ. 1329, Environ. Can., Can. For. Serv., Pac. For. Res. Cent. Victoria, BC. 